The researches allow provide increasing of a reliability degree of the estimation of biological value both already existing food products and improved ones.

Key words: flax, germination, DIAAS, sprouts, amino acid, protein quality, biological value, functional food.

\title{
REFERENCES
}

1. Protein quality evaluation: report of the Joint FAO/WHO Expert Consultation, Rome[Electronic resource]: FAO, 1991. - 66 p. Access mode: http://apps.who.int/iris/bitstream/10665/38133/1/9251030979_eng.pdf(дата обращения 26.04.2017).

2. FAO/WHO, (2013). Dietary protein quality evaluation in human nutrition Report of an FAO Expert Consultation FAO Food and nutrition 92, Rome, Italy 2013.

3. A. Babich, A. Babich-Poberezhnaya AA World resources of vegetable protein // Breeding and seed production. -2008 - Issue $96 .-$ P.215-222.

4. Patent of Ukraine for invention UA 95081 C2, A23L 1/0526 (2006.1) A23L 1/172 (2006.01). Free gluten-free flaxseed germs and their by-products, as well as their production and application. / Feglein Ferents HU, BIOGRIN A / S DK. - № a200803668; Declared 06.09.2005; published on 07/11/2011. - Bulletin No. 13/2011.

5. M. Oboznaya, F. Perceive, L. Shilman Prospects for the replacement of vegetable protein concentrates of oilseeds in the confectionery industry. // Technology and products of healthy nutrition 14: Materials Int. VIII scientific practice. Conf., 2 November 27, 14: Collection of scientific works of Saratov: FGBOOU VPO "Saratov GAU".

6. L. Eastwood and P. Leterme, 2010. Nutritional value of flaxseed meal for swine and its effects on the fatty acid profile of the carcass. Journal of animal science.

7. V. Zubtsov, L. Osipova, T. Lebedeva. Flax seeds its composition and properties.// Ross. chem mag. (Zh. Russian Chemical Society named after DI I. Mendeleev), 2002, vol. XLVI, No.2. - P.14-16.

8. O. Samochenko, M. Markucheva. Sprouted grain is a promising raw material for the development of new types of products. // New University. International scientific journal. - 2015. - № 7-8. - P.27-32.

Надійшла 25.06.2018. До друку 03.08.2018. Рецензія 03.08.2018

Адреса для переписки: вул. Канатна, 112, м. Одеса, 65039

Д.О.ЖИГУНОВ, д-р техн. наук, доцент, О.С. ВОЛОШЕНКО, канд. техн. наук, доцент,

Н.В. ХОРЕНЖИЙ, канд. техн. наук, доцент

Одеська національна академія харчових технологій, м. Одеса

\section{ПОРІВНЯЛЬНЕ ДОСЛІДЖЕННЯ ПОКАЗНИКІВ ЯКОСТІ ЦІЛЬНОЗЕРНОВОГО ПШЕНИЧНОГО ТА СПЕЛЬТОВОГО БОРОШНА ВІТЧИЗНЯНОГО ВИРОБНИЦТВА}

\footnotetext{
Анотація

Стаття присвячена обтрунтуванню необхідності розщирення асортименту борошняної продукції та підвищення іï харчової і біологічної иінності за рахунок виробництва иільнозернового пшеничного борошна.

У статі описані основні завдання та проблеми, щуо стоять перед сучасною зернопереробною промисловістю. Розглянуто переваги иільнозернового борошна, зокрема його підвищена біологічна иінність. Однак, иільнозернове борошно, отримане за різними технологіями виробництва, істотно відрізняється за показниками якості. Здійснено огляд наукових праць, спрямованих на аналіз існуючих в світі вимог на ией вид борочна. Стандарти України на циільнозернове пшеничне борошно на сьогоднішній день відсутні. ГСТУ 46.004-99 «Борошно пшеничне. Технічні умови» розповсюджуються тільки на борошно сортове та оббивне, проте виробники його виготовляють.

Метою роботи було дослідження показників якості иільнозернового пшеничного борошна, яке виробляється 6 Украӥні. У якості об'єкту досліджень використовували (за власною назвою виробника) борочно иільнозернове жорнового помелу пшеничне (обойне), борошно пшеничне обойного сорту, борошно иільнозернове жорнового помелу зі спельти (обойне), борошно иільнозернове жорнового помелу зі спельти, борошно пшеничне грубого помелу органічне, борочно пшеничне иільнозернове, борошно пшеничне особливе грубого помелу, борошно жорнове пшеничне цільнозернове, борошно цільнозернове пшеничне грубого помелу, яке було вироблено на вітчизняних підприємствах.

Вологість усіх зразків цільнозернового борошна не перевищувала 15,0%, щчо відповідає вимогам до пшеничного борошна. Зольність досліджуваних зразків иільнозернового борошна вітчизняного виробництва знаходилась у межах 1,12-1,58 \%. Судячи з показників зольності та крупності ряд виробників при його виробництві дотримуються принципу майже 100-відсоткового потрапляння усіх анатомічних складових зерна у иільнозернове борошно, але при иьому крупність борочна може бути на рівні крупності оббивного борочна, або істотно від нього відрізняться. Випечений хліб відрізнявся розвиненою, рівномірною пористістю, гладкою, без бічних підривів поверхнею скоринки, мав приємний смак і аромат.

Дослідження технологічних, хлібопекарських показників якості иільнозернового пшеничного та спельтового борошна вітчизняного виробництва показало зовсім різні кінщеві результати, щуо обумовлено різними технологічними підходами та відсутністю загальної нормативної документачії.

Доведено, щзо для поліпшення споживчих властивостей та підвищення конкурентоспроможності иільнозернового хліба необхідно встановити конкретні вимоги до якості иільнозернового борошна та дослідити їх вплив на хлібопекарські
} 
властивості, встановити оптимальний гранулометричний склад борошна з метою підвищення його хлібопекарських властивостей, вдосконалити режими випічки з урахуванням показників якості ияільнозернового борошна.

Ключові слова: иільнозернове пшеничне борошно, зерновий хліб, показники якості, гранулометричний склад, хлібопекарські властивості, харчова иінність

\section{Вступ}

Однією з основних завдань вітчизняної борошномельно-круп'яної промисловості є насичення ринку новими високоякісними та безпечними зерновими продуктами, здатними збалансувати і впорядкувати структуру харчування.Перед сучасною зернопереробною промисловістю стоїть низка актуальних проблем, вирішення яких необхідно для підвищення конкурентоспроможності вітчизняних продуктів переробки зерна на європейському ринку, підвищення коефіцієнта використання зерна, зниження енергоємності технологічного процесу переробки зерна і розширення асортименту готової продукції з підвищеною харчовою і біологічною цінністю.

\section{Літературний огляд}

При виробництві борошна понад 70 \% від усій електроенергії, що витрачається, припадає на процес подрібнення зерна. Традиційний сортовий помел зернових культур заснований на поступовому подрібнюванні зерна і механічному розподілі трьох його основних частин - ендосперму, зародка і оболонок, які суттєво різняться своїми фізико-механічними властивостями і хімічним складом. Це досягається за рахунок використання великої кількості подрібнюючих систем, що призводить до великих затрат електроенергії на виробництво сортового борошна[1].

Крім того, при відділенні від ендосперму оболонок, алейронового шару і зародка видаляється велика частина вітамінів, білкових і мінеральних речовин, що в свою чергу знижує біологічну цінність борошна в порівнянні з зерном та, як наслідок, знижуєхарчову цінність хліба. У порівнянні 3 пшеничним борошном вищого сорту цільнозернове борошно містить в 12,5 разів більше клітковини, в 2,1 рази більше кальцію, в 5,8 разів - магнію, в 3,9 рази - фосфору, в 3,4 рази - заліза, в 3,7 рази - вітаміну РР, в 2,3 рази - вітаміну $\mathrm{B}_{1}, \mathrm{~B}_{2}$. Окрім того,цільнозернове борошно містить вітамін $\mathrm{E}$, який повністю відсутній у борошні вищого сорту[2].

Виробництво цільнозмеленого борошна дозволяє зберегти всю природну поживну цінність зерна та забезпечити споживача біологічно активними речовинами. Цільнозернове пшеничне борошно може бути використане при виробництвіхліба, хлібобулочних та макаронних виробів підвищеної харчової цінності [3-7].

\section{Постановка проблеми}

Існує декілька технологій переробки зерна у цільнозернове борошно. В якості подрібнюючого обладнання можуть бути використані вальцьові верстати, дробарки чи кам'яні жорнова. Також є практика використання комбінованих технологічних схем, де в якості основного подрібнюючого обладнання використовують вальцьові верстати, а на останніх системах подрібнення встановлюють жорновий посад чи дробарку. Цільнозернове борошно, отримане за різ- ними технологіями виробництва, істотно відрізняється за показниками якості [2].

В більшості країн світу вологість борошна не повинна перевищувати 14,5-15,0 \% (винятком $\epsilon$ Франція, вологість обмежується на рівні не більше 16,0 \%). В деяких країнах у стандартах на цільнозернове борошно присутні обмеження верхнього і нижнього рівня зольності - це США (1,6-1,8\%), Великобританія (1,6-2,2 \%) та Канада (1,07-1,94 \%). У Німеччині передбачено виробництво трьох типів борошна 3 підвищеним вмістом баластних речовин з зольністю від 1,60 до 1,85 \%. Найбільша зольність борошна регламентована в Болгарії (борошно грубого помелу 3 зольністю не більше 1,85 \%), Польщі (борошно Грехамз зольністю не більше $1,85 \%$, борошно оббивне 3 зольністю не менше 2,00 \%), Великобританії (борошно 3 цільнозмеленого зерна з зольністю 1,60-2,20 \%) та Канаді (борошно грубого помелу зі зольністю 1,07-1,94\%).

Стандарти деяких країн регламентують вміст клейковини у цільнозерновому пшеничному борошні: Болгарія - у борошні грубого помелу не менше $26,5 \%$, Польща - у борошніГрехам не менше $24,0 \%$, Чехія - у борошні оббивному не менше 23,0 \%, у борошнігрубого помелу не менше 22,0 \%, США - у борошні з цільнозмеленого зерна не менше 14,0 \%.

Стандарти України на цільнозернове пшеничне борошно на сьогоднішній день відсутні. ГСТУ 46.004-99 «Борошно пшеничне. Технічні умови» розповсюджуються тільки на борошно сортове та оббивне.

Тому метою роботи було дослідження показників якості цільнозернового пшеничного борошна, яке виробляється в Україні.

\section{Матеріали і методи}

У якості об'єкту досліджень використовували (за власною назвою виробника) борошно цільнозернове жорнового помелу пшеничне (обойне), борошно пшеничне обойного сорту, борошно цільнозернове жорнового помелу зіспельти (обойне), борошно цільнозернове жорнового помелу зі спельти, борошно пшеничне грубого помелу органічне, борошно пшеничне цільнозернове, борошно пшеничне особливе грубого помелу, борошно жорнове пшеничне цільнозернове,борошно цільнозернове пшеничне грубого помелу, яке було вироблено на вітчизняних підприємствах.

Визначення органолептичних показників, вологості, білості, крупності, кількості та якості клейковини у борошні проводили за стандартними методиками.Дослідження хлібопекарських властивостей борошна проводили за допомогою прямого методу, тобто оцінки якості борошна за пробною випічкою.Стандарт на метод пробної лабораторної випічки хліба [8] передбачає безопарний спосіб приготування тіста 3 борошна, води, дріжджів хлібопекарських пресованих і солі.Оцінку якості хліба здійснювали 
за фізико-хімічними показниками згідно з ГОСТ 27669-88.

\section{Результати дослідження та їх обговорення}

Вітчизняний ринок пропонує споживачеві достатньо широкий вибір цільнозернового пшеничного борошна (табл. 1).

Аналіз пакування та маркування продукту (за даними виробника)показав, що зразки борошна 15вироблені згідно з ГСТУ 46.004-99, якість борошна зразків 6-9контролюється за власними технічними умовами виробника.

Дослідження якості борошна розпочинають iз визначення органолептичних показників, вологості, білості, крупності, кількості та якості клейковини (табл. 2).

Вологість усіх зразків цільнозернового борошна не перевищувала 15,0\%, що відповідає вимогам до пшеничного борошна[9]. Найменша вологість спостерігалась у зразках 2, 3, 8 .

Зольність досліджуваних зразків цільнозерновогоборошна вітчизняного виробництва знаходилась у межах 1,12-1,58 \%. Найвищі показники зольності (1,37-1,58\%) на рівні або незначно нижче цільного зерна пшениці або спельти відмічені у зразках 1-5, які за даними виробника вироблені за ГСТУ 46.004-99, найнижчі показники зольності $(1,12-1,26$ $\%$ - у зразках 6-9, виробленими за власними технічними умовами виробника.

Крупність борошна грубого помелу (оббивного пшеничного борошна) згідно зі стандартами контролюють двома ситами: залишком на ситі№ 067, та проходом сита № 38.Крупність досліджуваних зразків борошна різко відрізнялась, так для зразків 1, 3 залишок на ситі № 067 знаходився в межах 3-6\%, зразків $2,4,5,6,7,9-0,4-1,0 \%$, зразку $8-16 \%$. Найбільший вміст дрібної фракції борошна (прохід сита № 38) в межах 50-60 \% відмічено у зразках 1, 2, 3, 6,

Таблиця 1 - Аналіз пакування та маркування продукту(дані виробника)

\begin{tabular}{|c|c|c|c|c|}
\hline № & Найменування продукту & $\begin{array}{c}\text { Термін } \\
\text { зберігання } \\
\end{array}$ & $\begin{array}{c}\text { Нормативний } \\
\text { документ }\end{array}$ & Maca, $\Gamma$ \\
\hline 1 & $\begin{array}{l}\text { Борошно цільнозернове жорнового помелу } \\
\text { пшеничне (обойне) }\end{array}$ & 10 місяців & ГСТУ 46.004-99 & $1000 \pm 2 \%$ \\
\hline 2 & Борошно пшеничне обойного сорту“Цільнозернове” & 12 місяців & ГСТУ 46.004-99 & $2000 \pm 2 \%$ \\
\hline 3 & $\begin{array}{l}\text { Борошно цільнозернове жорнового помелу із спельти } \\
\text { (обойне) }\end{array}$ & 10 місяців & ГСТУ 46.004-99 & $1000 \Gamma \pm 2 \%$ \\
\hline 4 & Борошно цільнозернове жорнового помелу зі спельти & 10 місяців & ГСТУ 46.004-99 & $1000 \pm 1 \%$ \\
\hline 5 & Борошно пшеничне грубого помелу органічне & 12 місяців & ГСТУ 46.004-99 & $1000 \pm 15 \Gamma$ \\
\hline 6 & Борошно пшеничне цільнозернове & 12 місяців & $\begin{array}{c}\text { ТУУ15.6-36594696- } \\
\text { 001:2009 }\end{array}$ & $1000 \pm 1 \%$ \\
\hline 7 & Борошно пшеничне особливе грубого помелу & 12 місяців & $\begin{array}{c}\text { ТУУ10.6-36580577- } \\
\text { 001:2012 } \\
\end{array}$ & $1000 \pm 1 \%$ \\
\hline 8 & Борошно жорнове пшеничне цільнозернове & 12 місяців & $\begin{array}{c}\text { ТУУ15.6-24582550- } \\
\text { 002:2004 } \\
\end{array}$ & $1000 \pm 1 \%$ \\
\hline 9 & Борошно цільнозернове пшеничне & 8 місяців & $\begin{array}{l}\text { ТУ У15.6-00952737- } \\
\text { 006:2002 }\end{array}$ & $1000 \pm 15 \Gamma$ \\
\hline
\end{tabular}

Таблиця 2 - Показники якості досліджсуваних зразків борочна

\begin{tabular}{|c|c|c|c|c|c|c|c|}
\hline \multirow{2}{*}{ 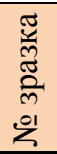 } & \multirow[b]{2}{*}{$\begin{array}{c}\text { Вологість, } \\
\%\end{array}$} & \multirow[b]{2}{*}{$\begin{array}{c}\text { Зольність, } \\
\%\end{array}$} & \multirow[b]{2}{*}{$\begin{array}{l}\text { Білість, } \\
\text { ум.од. }\end{array}$} & \multicolumn{2}{|c|}{ Клейковина } & \multicolumn{2}{|c|}{ К Крупність, \% } \\
\hline & & & & $\begin{array}{l}\text { вміст, } \\
\%\end{array}$ & $\begin{array}{l}\text { якість, } \\
\text { ум.од. }\end{array}$ & $\begin{array}{c}\text { залишок на } \\
\text { ситі №067 }\end{array}$ & $\begin{array}{c}\text { прохід сита } \\
\text { №38 }\end{array}$ \\
\hline 1 & 12,0 & 1,58 & $-29,0$ & 27 & 88 & 6,0 & 60 \\
\hline 2 & 10,6 & 1,37 & $-9,5$ & 21 & 65 & 0,2 & 49 \\
\hline 3 & 10,8 & 1,46 & $-2,7$ & 36 & 79 & 3,0 & 56 \\
\hline 4 & 11,4 & 1,41 & $-0,5$ & 32 & 81 & 1,0 & 50 \\
\hline 5 & 11,3 & 1,39 & $-0,5$ & 25 & 68 & - & 30 \\
\hline 6 & 12,2 & 1,12 & 30,4 & 26 & 74 & 0,4 & 51 \\
\hline 7 & 12,3 & 1,15 & 6,1 & 24 & 75 & - & 50 \\
\hline 8 & 10,9 & 1,26 & $-15,9$ & Не відм. & - & 16 & 30 \\
\hline 9 & 12,8 & 1,13 & 19,7 & 21 & 71 & 0,6 & 62 \\
\hline$* *$ & $\begin{array}{c}\text { Небіль- } \\
\text { ше15,0 }\end{array}$ & $\begin{array}{c}\text { Небільше } \\
2,0 \\
\end{array}$ & $\begin{array}{c}\text { Не обмежу- } \\
\text { ється }\end{array}$ & $\begin{array}{c}\text { Не менше } \\
18 \\
\end{array}$ & $\begin{array}{c}\text { Не нижче } \\
\text { ІІгр } \\
\end{array}$ & Небільше 2 & Не менше 35 \\
\hline
\end{tabular}


Таблиця 3 - Фізико-хімічні показники хліба з цільнозернового борочна

\begin{tabular}{|c|c|c|c|c|}
\hline $\begin{array}{c}\text { № } \\
\text { зразка }\end{array}$ & Найменування продукту & $\begin{array}{c}\text { Об'єм } \\
\text { хліба, } \text { см }^{3}\end{array}$ & $\begin{array}{l}\text { Порис- } \\
\text { тість, \% }\end{array}$ & $\begin{array}{l}\text { Питомий об'єм } \\
\text { хліба, см }{ }^{3} / \Gamma\end{array}$ \\
\hline 1 & $\begin{array}{l}\text { Борошно цільнозернове жорнового помелу пшеничне } \\
\text { (обойне) }\end{array}$ & 375 & 64 & 1,7 \\
\hline 2 & Борошно пшеничне обойного сорту “Цільнозернове” & 434 & 66 & 2,0 \\
\hline 3 & $\begin{array}{l}\text { Борошно цільнозернове жорнового помелу зі спельти } \\
\text { (обойне) }\end{array}$ & 500 & 69 & 2,2 \\
\hline 4 & Борошно цільнозернове жорнового помелу зі спельти & 520 & 70 & 2,4 \\
\hline 5 & Борошно пшеничне грубого помелу органічне & 455 & 70 & 2,1 \\
\hline 6 & Борошно пшеничне цільнозернове & 590 & 75 & 2,8 \\
\hline 7 & Борошно пшеничне особливе грубого помелу & 475 & 70 & 2,1 \\
\hline 8 & Борошно жорнове пшеничне цільнозернове & 255 & 47 & 1,2 \\
\hline 9 & Борошно цільнозернове пшеничне & 430 & 68 & 2,0 \\
\hline
\end{tabular}

7 та 9. У зразках 5, 8 вміст відповідної фракції борошна склав $30 \%$, що менше, ніж рекомендовано ГСТУ 46.004-99.

Судячи з показників зольності та крупності ряд виробників при його виробництві дотримуються принципу майже 100-відсоткового потрапляння усіх анатомічних складових зерна у цільнозернове борошно, але при цьому крупність борошна може бути на рівні крупності оббивного борошна, або істотно від нього відрізняться. Це залежить від виду здрібнюючих машин (жорнові постави чи вальцьові верстати), а також від застосування у технологічній схемі додаткового подрібнення висівок або ні. Інші виробники при формуванні цільнозернового борошна для покращення його хлібопекарських властивостей дотримуються принципу виключення певної частки оболонкових частинок у вигляді висівок, тому таке борошно має зольність значно меншу ніж у зерні, але також його крупність залежить від різної побудови та режимів процесу його розмелу.

Одним з основних показників, що характеризують хлібопекарські властивості борошна, $є$ кількість і якість сирої клейковини. Кількість клейковини, а також ії якість залежить як від сортових особливостей зерна, умов його зростання, так і від крупності борошна. Що стосується якості зерна, то також підхід до вибору сировини у різних виробників неоднорідний. Одні виробники отримують цільнозернове борошно з високоякісної пшениці, що обумовлює i більш високі хлібопекарські властивості і високу вартість такого борошна, інші дотримуються підходу використання більш дешевої слабкої пшениці. Крім пшениці деякі виробники застосовують дороге зерно пшениці спельти, що підвищує харчову цінність хліба та також впливає на хлібопекарські властивості борошна.

Вміст та якість клейковини в борошні мають вирішальне значення у визначенні структурномеханічних властивостей тіста і хлібопекарських достоїнств борошна.За вимогами ГСТУ 46.004-99 до показників якості оббивного борошна вміст клейковини обмежується на рівні не менше $18 \%$.

Найбільший вміст клейковини відмічено у зразках 3, 4 (спельтовому борошні) - 32 та 34 \% відповідно, у зразках 1, 5, 6, 7 вміст клейковини складає 25-27\%, найменший вміст сирої клейковини відмічено у зразках 2 та $9-21 \%$. У зразку борошна №8 клейковина не відмивається.

Дослідження хлібопекарських властивостей борошна проводили за пробною випічкою і оцінкою хліба, отриманого 3 досліджуваного зразка.Аналіз якості готових виробів проводили за органолептичними та фізико-хімічними показниками якості. Результати пробної випічки хліба 3 досліджуваних зразків борошна наведено у табл. 3 .

Випечений хліб відрізнявся розвиненою, рівномірною пористістю, гладкою, без бічних підривів поверхнею скоринки, мав приємний смак i аромат.Найбільший об'єм хліба та високу пористість майже на рівні сортового борошна мав зразок 6 $590 \mathrm{~cm}^{3}$ та 75 \%, відповідно. Цей зразок також характеризувався низькою зольністю, що свідчить про те, що при його виробництві частка високозольних висівок була відокремлена і не потрапила у борошно.

Високий об'єм хліба спостерігався у зразках борошна 3, 4, 7.Це пов'язано насамперед 3 високим вмістом і якістю клейковини (понад $24 \%$ )та крупністю борошна вказаних зразків (прохід сита №38 складає 50-56 \%). Пористість хліба знаходиться на рівні $70 \%$.

Зразок борошна №8 мав найменший об'єм хліба серед досліджуваних зразків, тому що має найслабший білковий комплекс, який не утворює клейковинний каркас. У цього хліба відмічена низька пористість $47 \%$.

\section{Висновки}

Цільнозернове пшеничне борошно дозволяє розширити асортимент та підвищити харчову цінність готової продукції. Але на сьогоднішній день 
стандарти на цільнозернове пшеничне борошно відсутні, тому показники якості цільнозернового борошна, представленого на вітчизняному ринку, коливаються у широких межах. Для того щоб обгрунтувати технологічну схему та режими виробництва цільнозернового пшеничного борошна, встановити конк- ретні вимоги до його якості необхідно встановити вимоги до якості зерна пшениці, дослідити вплив основних показників борошна на його хлібопекарські властивості, встановити оптимальний гранулометричний склад борошна з метою підвищення його хлібопекарських властивостей.

\section{ЛITEPATУPA}

1. Grinding Characteristics of Wheat in Industrial Mills// [Електронний ресурс]. - Режим доступу: http://dx.doi.org/10.5772/53160

2. Оспанов А.А., Тимурбекова А.К. Технология производства иельносмолотой муки: Учебное пособие. - Алматы: ТОО "Нур-Принт", 2011.-114c.

3. Миколенко С.Ю. Дослідження технологічних аспектів виробництва хліба з диспергованої зернової маси з використанням додаткової підготовки сировини / С.Ю. Миколенко, В.Ю. Соколов, В.В. Пенькова // Зернові продукти $і$ комбікорми - 2016. - vol. 64, I.4 - c.10-15.https://doi.org/10.15673/gpmf.v64i4.260

4. Макарова О.В. Трехкомпонентные смеси в технологии зернового хлеба / О.В. Макарова, А.С. Иванова, Н.Ю. Соколова // Зернові продукти і комбікорми - 2016. - vol. 64, I.4 - c.4 - 9.https://doi.org/10.15673/gpmf.v64i4.259

5. Akhtar S, Ashgar A. 2011. Mineral fortification of whole wheat flour. In: Flour and Breads and their Fortification in Health and Disease Prevention. New York: Elsevier. p. 263-71.

6. Manthey, F.A., Schorno, A.L., 2002. Physical and cooking quality of spaghetti madefrom whole wheat durum. Cereal Chem. 79. p.504-510.

7. Юрчак В.Г. Дослідження макаронних властивостей цільнозернового пшеничного борочна / В. Г. Юрчак, Г. В. Карпик, Т. П. Голікова // Наукові прачі Національного університету харчових технологій - 2012.- № 47. - c.123-128.

8. ГОСТ 27669-88.«Мука пшеничная хлебопекарная. Метод пробной лабораторной выпечки хлеба». - М.: 1988. - 9 c.

9. ГСТУ 46.004-99. «Борошно пиеничне. Технічні умови». - Київ, 1999. - 9 с.

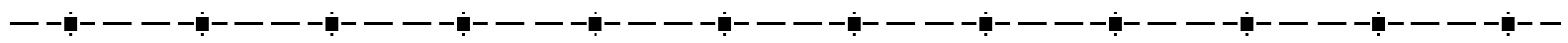

D.O. ZHYHUNOV, DSc Tech, Ass. professor, O.S. VOLOSHENKO, PhD., Ass. professor, Candidate of technical science, N.V. KHORENGHY, PhD., Ass. professor, Candidate of technical science

Odessa National Academy of Food Technologies, Ukraine

\section{COMPARATIVE STUDY OF THE QUALITY INDICES OF THE WHOLE GRAINW- HEAT AND SPELTA FLOUR OF THE DOMESTIC PRODUCTION}

Abstract

The article is devoted to the substantiation of the necessity of expanding the range of flour products and increasing its nutritional and biological value at the expense of production of whole wheat flour.

The paper describes the main challenges and challenges faced by the modern grain-processing industry. The advantages of whole wheat flour, in particular its increased biological value, are examined. However, whole-wheat flour, obtained by different production technologies, differs significantly in terms of quality. An overview of scientific works aimed at analyzing the world's requirements for this type of flour is carried out. Ukraine's standards for whole wheat flour are currently absent. GOST 46.004-99 "Wheat flour. Specifications "apply only to varietal and upholstery flour, but manufacturers make it.

The aim of the work was to study the quality indices of whole wheat flour, which is produced in Ukraine. As a research object, flour was used (by producer's name): whole grain grindstone wheat flour (dark), low-gradewheat flour, whole grain grindstone spelta flour (dark), whole grain grindstone spelta flour, coarse organic wheat flour, whole grain wheat flour, coarse special wheat flour, whole grain grindstone wheat flour, coarse whole grain wheat flour, which were produced at domestic enterprises.

The moisture content of all samples of whole wheat flour did not exceed $15.0 \%$, which corresponds to the requirements for wheat flour. The ashcontentof investigated samples of whole wheat flour of domestic production was within the range of 1.12-1.58\%. Judging by the indexes of ash content and the granularity of a number of producers in its production adhere to the principle of almost 100 percent penetration of all the anatomical components of grain into whole grain flour, but the granularity of the flour can be at the level of size of dark flour, or significantly different from it. Baked bread was characterized by the developed and uniform porosity, smooth crust without lateral undermining,it had a pleasant taste and aroma.

Research of technological, baking quality indices of whole wheat and spelta flour of domestic production showed completely different results due to different technological approaches and lack of general normative documentation.

It is proved that in order to improve the consumer properties and increase the competitiveness of bread from whole wheat flour, it is necessary to establish specific requirements for the quality of whole wheat flour and to investigate their influence on baking properties, to establish the optimum granulometric composition of flour in order to increase its bakery properties, to improve the baking modes taking into account quality indices of whole grain flour.

Keywords: whole grain wheat flour, grain bread,quality indices, granulometric composition, bakery properties, nutritional value

\section{REFERENCES}

1. Grinding Characteristics of Wheat in Industrial Mills // Elektronniyresurs. Rezhimdostupu:: http://dx.doi.org/10.5772/53160

2. Ospanov A.A., Tymurbekova A.K.Technology of production of whole-wheat flour: Textbook. - Almaty: LLP "Nur-Print", 2011. - $114 p$.

3. Mykolenko S.Iu. Studyoftechnologicalaspectsofgrainbreadproductionwithusingadditionaltreatmentofrawmaterials/ Mykolenko, S.Yu., Sokolov, V.Yu., \& Penkova, V.V. // Grain Products and Mixed Fodder's - 2016. - vol. 64, I.4 - c.10-15.

4. MakarovaO.V. Three-componentmixturesingrainbreadtechnology / O.V. Makarova, A.S. Yvanova, N.Iu. Sokolova // Grain Products and Mixed Fodder's-2016. - vol. 64, I.4 - c.4 - 9. 
5. Akhtar S, Ashgar A. 2011. Mineral fortification of whole wheat flour. In: Flour and Breads and their Fortification in Health and Disease Prevention. New York: Elsevier. p. 263-71.

6. Manthey, F.A., Schorno, A.L., 2002. Physical and cooking quality of spaghetti madefrom whole wheat durum. Cereal Chem. 79. p.504-510.

7. Yurchak V.G. Researchofmacaronipropertiesofwholewheatflour / VG Yurchak, G.V. Karpyk, T.P. Golikova // ScientificpapersoftheNationalUniversityofFood Technologies - 2012.- No. 47. - p.123-128.

8. GOST 27669-88 "Wheat flour baking. Method of trial laboratory bread baking ". M.: 1988. - 9 p.

9. GSTU 46.004-99. "Flouriswheat. Specifications". - Kyiv, 1999. - 9 p.

Надійшла 28.08.2018. До друку 12.09.2018. Рецензія 29.08.2018

Адреса для переписки:

ОНАХТ, вул. Канатна, 112, м. Одеса, 65039

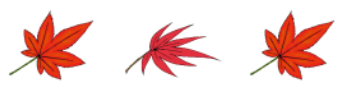

УДК 664.64.016.8:338.33:338.439.5

Н.Ю. СОКОЛОВА, канд. техн. наук, ст. викладач, О.М. КОТУЗАКИ, канд. техн. наук,

ст. викладач, Л.Г. ПОЖИТКОВА, канд. техн. наук, асистент

Одеська національна академія харчових технологій, м. Одеса

\section{АНАЛІЗ ПРОБЛЕМ ХЛІБОПЕКАРСЬКОЇ ГАЛУЗІ, СТАН РИНКУ ТА АКТУАЛЬНІ ШЛЯХИ РОЗШИРЕННЯ АСОРТИМЕНТУ}

Анотація

Хлібопекарська промисловість України має велике сочіальне значення, вона є підтримкою стабільності у суспільстві, а підприємства, щзо виробляють такий значимий для кожного пересічного україния продукт харчування, як хліб, прагнуть задовольнити потреби усіх верств населення. Тим не менш, не дивлячись на таку значимість, останнім часом у галузі спостерігаються негативні прочеси, що істотно впливають не лише на якість виробів, а й на загальні тендениії у виробництві та реалізації продукиії. В даній статті проаналізовано основні проблеми хлібопекарської промисловості, розглянуто стан ринку хлібобулочних виробів у иььому аспекті та запропоновано актуальні шляхи розширення асортименту. Вибір напрямів впровадження інноваційних засад має трунтуватися на індивідуальних потребам кожного окремо взятого виробництва і бути начіленим на конкретну групу споживачів. Саме такий підхід має забезпечити гарантований результат.

Останнє десятиліття ичіла група хлібобулочних виробів, залишається поза увагою великих підприємств та науковців, розроблені за останні роки основні конщептуальні підходи до розвитку нових технологій хлібобулочних виробів рідко стосуються сухарних виробів. Тим не менш, їх можна розглядати як перспективну групу хлібобулочних виробів, щуо за рахунок оптимізація параметрів тістоприготування, складу харчових добавок багатофункціонального дї дасть можливість отримати додатковий прибуток, оскільки їх вартість значно відрізняється від вартості сочіально значимого хліба, окрім того строки реалізачії хлібобулочних виробів пониженої вологості дають можливість розглядати їх навіть як групу виробів, щчо можуть імпортуватися.

Створення нових технологій сухарних виробів поліпшеної якості на основі регулювання біотехнологічних процесів виробництва дозволить розиирити асортимент та популяризувати цей продукт харчування. Модернізація існуючих шляхів удосконалення якості хлібобулочних виробів пониженої вологості, які включають як використання поліпшувачів різної природи, так $і$ застосування технологічних прийомів та рішень дозволить перевести такі вироби у площину дієтичного та спеціального призначення. Оскільки в світлі останніх досягнень в області науки про харчування пріоритетним є створення асортименту виробів пониженої вологості для дієтичного та спеціального харчування.

Ключові слова: ринок хлібобулочних виробів Украӥни, хлібобулочні вироби пониженої вологості, технологічні рішення, якість.

Хлібопекарська промисловість України посідає в системі АПК одне з провідних місць, тому що виконує завдання $з$ виробництва для населення традиційно важливої продукції першої необхідності, яка відрізняється широким асортиментом. У загальному обсязі валової продукції харчової промисловості частка хлібопекарської промисловості становить понад 15\%; питома вага iї виробничих основних фондів в основних фондах харчової промисловості - 8\% [1, 2].

За даними дослідницької компанії GfK Ukraine, споживання хліба в Україні кожного року падає $\mathrm{i}$ спостерігається така тенденція з 2008 року, особливо за рахунок продукції, що відноситься до низького цінового сегмента. Сьогодні ринок хліба та хлібобулочних виробів значно різниться як за асортиментом так і за виробниками. Згідно даних маркетингових досліджень компанії «Maxrise consulting» основними гравцями ринку $є$ : «Київхліб», «Хлібні інвестиції», «Кулінічі», «Група Лауффер», «Формула смаку», «Концерн Хлібпром» та інші. Сумарна доля інших виробників складає 48,1\% [3]. Узагальнивши всі проблеми, які на сьогодні постають перед виробниками хлібопекарської продукції, можна резюмувати, що в основному зниження рівня виробництва хлібобулочних виробів в Україні протягом останнього десятиліття було зумовлено рядом факторів $[4,5]$. 